Research article

Open Access

\title{
Human meniscus cells express hypoxia inducible factor-1 $\alpha$ and increased SOX9 in response to low oxygen tension in cell
} aggregate culture

\author{
Adetola B Adesida1,2, Lisa M Grady¹, Wasim S Khan¹, S Jane Millward-Sadler,4, Donald M Salter ${ }^{3}$ \\ and Timothy $\mathrm{E}$ Hardingham ${ }^{1}$
}

\author{
1UK Centre for Tissue Engineering (UKCTE) and The Wellcome Trust Centre for Cell-Matrix Research, Faculty of Life Sciences, The University of \\ Manchester, Michael Smith Building, Oxford Road, Manchester, M13 9PT, UK \\ ${ }^{2}$ CellCoTec, Professor Bronkhorstlaan 10-D, Bilthoven 3723 MB, The Netherlands \\ ${ }^{3}$ The University of Edinburgh, Queens Medical Research Inst, Little France Crescent, Edinburgh, EH16 4TJ, UK \\ ${ }^{4}$ Division of Regenerative Medicine, University of Manchester, Oxford Road, Manchester M13 9PT, UK \\ Corresponding author: Timothy E Hardingham, timothy.e.hardingham@manchester.ac.uk
}

Received: 27 Oct 2006 Revisions requested: 4 Dec 2006 Revisions received: 6 Jul 2007 Accepted: 18 Jul 2007 Published: 18 Jul 2007

Arthritis Research \& Therapy 2007, 9:R69 (doi:10.1186/ar2267)

This article is online at: http://arthritis-research.com/content/9/4/R69

(c) 2007 Adesida et al.; licensee BioMed Central Ltd.

This is an open access article distributed under the terms of the Creative Commons Attribution License (http://creativecommons.org/licenses/by/2.0), which permits unrestricted use, distribution, and reproduction in any medium, provided the original work is properly cited.

\begin{abstract}
In previous work we demonstrated that the matrix-forming phenotype of cultured human cells from whole meniscus was enhanced by hypoxia ( $5 \%$ oxygen). Because the meniscus contains an inner region that is devoid of vasculature and an outer vascular region, here we investigate, by gene expression analysis, the separate responses of cells isolated from the inner and outer meniscus to lowered oxygen, and compared it with the response of articular chondrocytes. In aggregate culture of outer meniscus cells, hypoxia (5\% oxygen) increased the expression of type II collagen and SOX9 (Sry-related HMG box-9), and decreased the expression of type I collagen. In contrast, with inner meniscus cells, there was no increase in SOX9, but type II collagen and type I collagen increased. The articular chondrocytes exhibited little response to $5 \%$ oxygen in aggregate culture, with no significant differences in the expression of these matrix genes and SOX9. In both aggregate
\end{abstract}

cultures of outer and inner meniscus cells, but not in chondrocytes, there was increased expression of collagen prolyl 4-hydroxylase $(\mathrm{P} 4 \mathrm{H}) \alpha(\mathrm{I})$ in response to $5 \%$ oxygen, and this hypoxia-induced expression of $\mathrm{P} 4 \mathrm{H} \alpha(\mathrm{I})$ was blocked in monolayer cultures of meniscus cells by the hypoxia-inducible factor (HIF)-1 $\alpha$ inhibitor (YC-1). In fresh tissue from the outer and inner meniscus, the levels of expression of the HIF- $1 \alpha$ gene and downstream target genes (namely, those encoding $\mathrm{P} 4 \mathrm{H} \alpha(\mathrm{I})$ and HIF prolyl 4-hydroxylase) were significantly higher in the inner meniscus than in the outer meniscus. Thus, this study revealed that inner meniscus cells were less responsive to $5 \%$ oxygen tension than were outer meniscus cells, and they were both more sensitive than articular chondrocytes from a similar joint. These results suggest that the vasculature and greater oxygen tension in the outer meniscus may help to suppress cartilage-like matrix formation.

\section{Introduction}

The meniscus serves as a critical fibrocartilaginous tissue in the biomechanics of the knee joint, and it plays an important role in load distribution and joint stability $[1,2]$. Its biomechanical importance is further highlighted by the high incidence of osteoarthritis after menisectomy [3-8]. The function of the meniscus is reflected in its cellular and biochemical composition, which ensures that shear, tensile and compressive forces are appropriately distributed in the knee joint [9]. The menis- cus exhibits regional and zonal variations in its cellular composition [9-13], reparative capacity $[14,15]$ and microstructure $[16,17]$. The cells of the outer one-third are fibroblast-like, with extensive cellular processes that may stain positively for CD34 and are within a dense connective tissue, which is composed predominantly of type I collagen fibre bundles aligned in the circumferential direction of the tissue, along with smaller amounts of proteoglycans and minor collagens including types III and V [16,18-21]. In contrast, cells from the middle and 
inner portions, accounting for the remaining two-thirds of the tissue, are with few processes $[17,22]$ and are negative for CD34 [21]. These cells have been termed fibrochondrocytes [17] and are surrounded by an extracellular matrix that is composed of collagen types I and II [17-19], with a higher content of aggrecan than in the outer region [22-24]. Based on morphological differences, the cells of the tissue have been further divided into three to four distinct populations [12].

The presence of type II collagen and aggrecan in the inner meniscus shows that this region has some similarities with articular cartilage [18-20,25]. However, the type II collagen in the meniscus is organized in a close network with collagen I fibres, which is in contrast to its diffuse fine fibre distribution in articular cartilage [19]. Further regional differences within the meniscus include the presence of vascular and neural components in the outer meniscus, which are absent from the inner region $[15,26]$. Perhaps as a consequence of the lack of blood supply, the reparative and regeneration potential of the inner meniscus is more limited than that of the outer region [14,27].

Cell-based tissue engineering strategies have been proposed to aid repair and to generate a meniscus substitute for implantation [13,28-32]. Meniscus cells may be appropriate for this strategy. However, during monolayer expansion of human meniscus cells there is increased expression of type I collagen and decreased expression of type II collagen, similar to the dedifferentiation in culture of chondrocytes [13].

Several investigators have exploited low oxygen tension during in vitro culture of chondrocytes as a strategy to restore differentiated phenotype [33-37]. This stems from the fact that conventional cell culture is performed in an atmosphere containing $20 \%$ oxygen tension, whereas cartilage in vivo, being avascular, has much lower oxygen tension (1\% to 7\%) [38-41]. We recently showed that the matrix-forming phenotype of cultured primary human meniscus cells was enhanced in lowered oxygen $(5 \%)[42,43]$, but the responses of cells isolated from the outer and inner regions were not investigated separately.

Recent studies have distinguished cells and tissue from the outer and inner regions of the meniscus by showing that cartilaginous marker genes, namely type II collagen and aggrecan, both exhibited significantly higher expression in cells or tissues derived from the inner region relative to cells or tissues from the outer meniscus $[23,24]$.

The objective of the current investigation was to determine whether hypoxia inducible factor (HIF)- $1 \alpha$ and downstream target genes that are involved in the adaptive response of cells and tissues to low oxygen tension were expressed differently in cells in the outer and inner regions of the human meniscus [44-48]. We also wished to determine whether the cells isolated from the outer and inner meniscus in culture differed in their response to lowered oxygen tension.

\section{Materials and methods Human meniscus and cartilage tissue source and cell isolation}

Human articular cartilage and meniscus was obtained, with informed consent and local ethical approval (Ethics Committee of South Manchester Health Care Trust), during total knee arthroplasty from seven patients (mean age 59 years, range 36 to 77 years) with osteoarthritis. The meniscus tissue was from intact samples of medial and lateral meniscus.

The tissue was cut into small pieces within 6 hours of surgery, before overnight digestion at $37^{\circ} \mathrm{C}$ with $0.2 \%$ (weight/vol) collagenase II (Worthington Biochemical Corp., Reading, UK) in Dulbecco's modified Eagles medium (DMEM) containing 10\% foetal calf serum (FCS). In addition, fresh tissue pieces from the inner and outer regions of samples of intact lateral meniscus were digested with collagenase, as described above, or preserved in RNAlater (Qiagen Ltd, Crawley, UK) for gene expression analysis. Tissue from the inner and outer regions represented pieces taken from about two-third and one-third of the radial distance, respectively. Isolated meniscus cells were seeded in a $75 \mathrm{~cm}^{2}$ tissue culture flask at $1 \times 10^{4}$ cells/ $\mathrm{cm}^{2}$ in a humidified atmosphere under $20 \%$ oxygen and $5 \%$ carbon dioxide at $37^{\circ} \mathrm{C}$ in DMEM. Cells were cultured in DMEM supplemented with 10\% FCS, 100 units/ml penicillin and 100 units $/ \mathrm{ml}$ streptomycin, with added L-glutamine (2 $\mathrm{mmol} / \mathrm{l}$; all from Cambrex, Wokingham, UK). The media was changed every 2 days, and on reaching confluence (within 2 weeks) the cells were passaged (passage one) into a $225 \mathrm{~cm}^{2}$ tissue culture flask. The cells were used in experiments at passage two or three of monolayer culture. Human chondrocytes were isolated from articular cartilage (obtained from the same individuals who donated menisci) by a sequential trypsin/collagenase digestion and also used in experiments at passage two or three of monolayer culture in DMEM with 10\% FCS, $100 \mathrm{units} / \mathrm{ml}$ penicillin and $100 \mathrm{units} / \mathrm{ml}$ streptomycin (all from Cambrex, Wokingham, UK).

\section{Three-dimensional cell aggregate culture}

Aggregates of second or third passage outer and inner meniscus cells or articular chondrocytes $\left(5 \times 10^{5}\right.$ cells per aggregate) were formed by centrifugation at 1,200 rpm for $5 \mathrm{~min}$ in a $15 \mathrm{ml}$ conical culture tube. The cell aggregates were cultured for 14 days in a humidified atmosphere under conditions of normoxia (95\% air and 5\% carbon dioxide [20\% oxygen]) or hypoxia (5\% oxygen, $5 \%$ carbon dioxide and $90 \%$ nitrogen) at $37^{\circ} \mathrm{C}$ in DMEM containing $10 \%$ FCS and chondrogenic medium. The chondrogenic medium was composed of the following [49]: ITS+1, dexamethasone $(10 \mathrm{nmol} / \mathrm{l})$ and ascorbate-2-phosphate ( $25 \mu \mathrm{g} / \mathrm{ml}$; all from Sigma, Poole, UK), and transforming growth factor $\beta_{3}(10 \mathrm{ng} / \mathrm{ml}$; R\&D Systems, Abingdon, UK). 
Table 1

\begin{tabular}{|c|c|}
\hline Primer & Sequence \\
\hline \multirow[t]{2}{*}{$\beta$-actin } & Forward 5'-3' AAGCCACCCСАСТTCT-СТCTAA \\
\hline & Reverse 5'-3' ААTGСТАТСАССТССССТGTGT \\
\hline \multirow[t]{2}{*}{ COL1A2 } & Forward 5'-3'TTGCCCAAAGTT-GTCCTCTTCT \\
\hline & Reverse 5'-3' AGCTTCTGTGGAACCATGGAA \\
\hline \multirow[t]{2}{*}{ COL2A1 } & Forward 5'-3' CTGCAAAATAAAATCTCGGTGTTCT \\
\hline & Reverse 5'-3' GGGCATTTGACTCACACCAGT \\
\hline \multirow[t]{2}{*}{ HIF-1 $\alpha$} & Forward 5-3' GTAGTTGTGGAAGT-TTATGCTAATATTGTGT \\
\hline & Reverse 5'-3' CTTGTTTACAGTCTGCTCA-AAATATCTT \\
\hline \multirow[t]{2}{*}{$\mathrm{P} 4 \mathrm{H} \alpha(\mathrm{I})$} & Forward 5'-3' GCAGGGTGGTAATATTGGCATT \\
\hline & Reverse 5'-3' AАATCAАTTСССТСАТСАСТGAAAG, \\
\hline \multirow[t]{2}{*}{$\mathrm{P} 4 \mathrm{H} \alpha(\mathrm{II})$} & Forward 5'-3'TTAGCTGTCTAGCGCCTAGCAA \\
\hline & Reverse 5'-3' TTTGGTTCACTGAAACA-TCTCACA \\
\hline \multirow[t]{2}{*}{$\mathrm{P} 4 \mathrm{H} \alpha(\mathrm{III})$} & Forward 5'-3' CTCAACAGTCTCAGGTTCGATCA \\
\hline & Reverse 5'-3' TTCTTGGTCCCTGTGGTCAAG \\
\hline \multirow[t]{2}{*}{ PHD2 } & Forward 5'-3'TGGCC-TATATGTGTTTAATCCTGGTT \\
\hline & Reverse 5'-3'TGTTTTACAGCTGGTTAATGTG-TTGA \\
\hline \multirow[t]{2}{*}{ SOX9 } & Forward 5'-3'CTTTGGTTTGTGTTCGTGTTTTG \\
\hline & Reverse 5'-3'AGAGAAAGAAAAAGGGAAAGGTAAGTTT \\
\hline
\end{tabular}

COL1A2, collagen type I alpha 2; COL2A1, collagen type II alpha 1; HIF, hypoxia inducible factor; P4H, prolyl 4-hydroxylase; PHD, HIF prolyl hydroxylase; SOX, Sry-related HMG box-9.

Meniscus cell incubation with hypoxia inducible factor$1 \alpha$ inhibitor (YC-1)

Cells cultured from whole meniscus at passage two were seeded onto a 12-well plate in DMEM with $10 \%$ FCS at $1 \times$ $10^{4}$ cells per well. The cells were allowed to adhere overnight under normoxia. HIF-1 $\alpha$ inhibitor, namely 3-(5'-hydroxymethyl2'furyl)-1-benzyl indazole (YC-1; Calbiochem, Nottingham, UK), in dimethylsulphoxide was added to DMEM with FCS at a final concentration of 1 to $50 \mu \mathrm{mol} / /$ and incubated with meniscus cells for 5 days under normoxic and hypoxic conditions. Control monolayer cultures were incubated with DMEM containing FCS and vehicle alone (dimethylsulphoxide; $0.6 \%$ $\mathrm{vol} / \mathrm{vol})$. The growth medium was changed every 2 days.

\section{Gene expression analysis}

Total RNA was prepared from meniscus tissue, monolayer cells and cell aggregate cultures using Tri-Reagent (Sigma, Poole, UK). To minimize changes in gene expression, cultures caps were closed before removal from the low oxygen tension incubator, and cell aggregates were immediately $(<1 \mathrm{~min})$ transferred into Tri-Reagent. Total RNA from fresh tissue was isolated after homogenization with a Braun mikrodismembranator (Biotech, Melsungen, Germany). Cell aggregate cultures were ground up in Tri-Reagent using Molecular Grinding Resin (Geno Technology Inc, St Louis, MO, USA). For gene expression analysis, cDNA was derived from 10 to $100 \mathrm{ng}$ total RNA using global amplification [50]. Samples were diluted 1:1000 and a $1 \mu$ aliquot was amplified by polymerase chain reaction in a $25 \mu \mathrm{l}$ reaction volume in an MJ Research Opticon 2 real-time thermocycler using a SYBR Green Core Kit (Eurogentec, Seraing, Belgium) with gene-specific primers designed using ABI Primer Express software (Applied Biosystems, Foster City, CA, USA). Relative expression levels were normalized to $\beta$-actin mRNA expression and calculated using the $2^{-\Delta \mathrm{Ct}}$ method [51]. All primer concentrations were 300 $\mathrm{nmol} / \mathrm{l}$ unless stated otherwise. All primers were from Invitrogen (Paisley, UK) and were designed based on human sequences as summarized in Table 1.

\section{Results}

HIF-1 $\alpha$, PHD2 and P4H $\alpha(\mathrm{I})$ expression in inner and outer meniscus

Expression levels of a panel of genes that are involved in cellular responses to low oxygen conditions were determined. The results showed that there was significantly higher expression of HIF-1 $\alpha$ (1.3- to 5.0-fold; $P<0.05$ to $P<0.01$ ), albeit with donor variability (Figure 1a); higher expression of HIF prolyl-hydroxylase (PHD)2 (5-fold; $P<0.01$ ); and higher expression of prolyl 4-hydroxylase $(\mathrm{P} 4 \mathrm{H}) \alpha(\mathrm{I})(6$-fold; $P<0.01)$ in samples from the inner region compared with the outer 
Figure 1

(a)

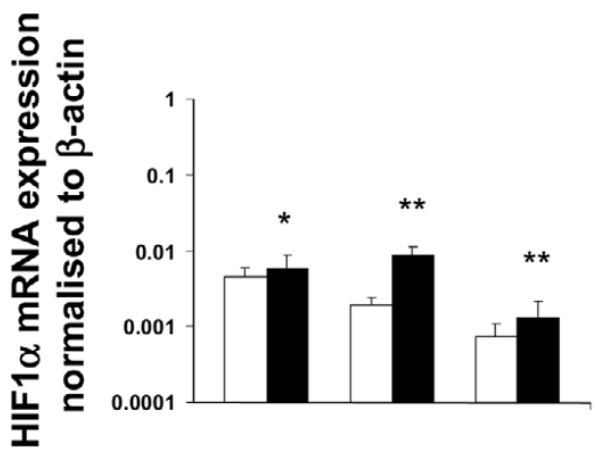

\begin{tabular}{|l|c|c|c|}
\hline $\begin{array}{c}\text { Outer (O) } \\
\text { Inner (I) }\end{array}$ & O I & O I & O I \\
\hline $\begin{array}{c}\text { Donor } \\
\text { samples }\end{array}$ & A & B & C \\
\hline
\end{tabular}

(b)

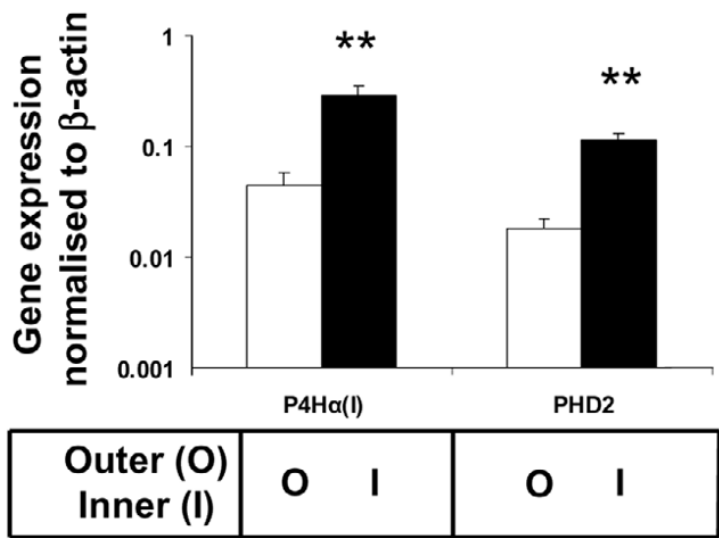

Gene expression of HIF- $1 \alpha$ and target genes in the outer and inner meniscus. (a) Hypoxia inducible factor (HIF)-1 $\alpha$ gene expression in the outer (O; white bars) and inner ( 1 ; black bars) region of meniscus tissue from three donors $(n=3)$. (b) Prolyl 4-hydroxylase (P4H) $\alpha(\mathrm{I})$ and HIF prolyl-hydroxylase (PHD)2 gene expression in the outer (O; white bars) and inner ( $\mathrm{l}$; black bars) region of meniscus tissue $(n=3)$. Values are expressed as mean \pm standard deviation. ${ }^{\star} P<0.05$, ${ }^{* \star} P<0.01$ (by Student's unpaired $t$-test) in inner versus outer region of the meniscus matched against the same donor.

region of the meniscus (Figure $1 \mathrm{~b}$ ). The inner region cells thus exhibited evidence of gene expression induced by low oxygen tension, which was absent from the outer region.

In order to determine whether these differences in expression in vivo were reflected in different responses inherent in the cells present in inner and outer meniscus, we isolated the cells from the outer and inner regions and expanded them in monolayer for two to three passages. At this stage the cells were fibroblastic in morphology, and the expression of type I collagen had increased and that of type II collagen had fallen very low (data not shown). To determine the effects of lowered oxygen on their matrix-forming ability, the cells from inner and outer meniscus were cultured separately in three-dimensional cell aggregates in chondrogenic medium in the presence of $5 \%$ or $20 \%$ oxygen for 14 days, and gene expression changes in type I collagen (COL1A2 [collagen type I alpha 2]), type II collagen (COL2A1 [collagen type II alpha 1]) and SOX9 (Sryrelated HMG box-9) were determined. Similar parallel experiments were performed with articular chondrocytes, so that the response of the three cell types to low oxygen tension culture could be compared.

After 14 days in 5\% oxygen, cells isolated from the outer meniscus exhibited a decrease in the expression of type I collagen by 18 -fold $(P<0.01)$ as compared with $20 \%$ oxygen (Figure 2a), whereas in cells from the inner meniscus type I collagen increased 2 -fold ( $P<0.05$; Figure $2 b$ ). In a parallel experiment with articular chondrocytes, the expression of type I collagen was unchanged in 5\% oxygen (Figure $3 a$ ).

Cells from the outer meniscus expressed type II collagen at a very low level in monolayer culture (data not shown), and when they were transferred to aggregate culture in 5\% oxygen they exhibited a very large increase $(15,300$-fold; $P<0.01)$ in its expression (Figure 2c). In contrast, the expression of type II collagen was higher in inner meniscus cells in monolayer than in outer meniscus cells (data not shown), but it increased only 7 -fold ( $P<0.05$; Figure $2 \mathrm{~d}$ ) in aggregate cultures in 5\% oxygen. The type Il collagen response to lowered oxygen was thus greater in the cells cultured from the outer meniscus. The cells from the outer meniscus also exhibited a greater increase in SOX9 expression (7-fold; $P<0.05$ ) in aggregate culture, whereas there was no increase in SOX9 in cells from the inner meniscus (Figure 2e,f). Under similar conditions in aggregate culture of articular chondrocytes in 5\% oxygen, the expression of type II collagen and SOX9 was unchanged (Figure $3 b, c$ ).

\section{Induction of collagen prolyl 4-hydroxylases}

Cellular adaptation to low oxygen tension in many cells is regulated by HIF-1, a heterodimer of HIF- $1 \alpha$ and HIF-1 $\beta$, which induces the transcription of a variety of hypoxia inducible genes. We therefore investigated the expression of a known HIF-1 target gene, namely that encoding collagen $\mathrm{P} 4 \mathrm{H} \alpha$ (types I, II and III), which is essential in collagen post-translational processing and fibril formation. The cells from the outer meniscus again exhibited a greater response to 5\% oxygen than did the cells from the inner meniscus. The expression of $\mathrm{P} 4 \mathrm{H} \alpha(\mathrm{I})$ isoenzyme was significantly increased (10.6-fold; $P<$ 0.01 ) in outer meniscus cells (Figure $4 \mathrm{a}$ ) as compared with the 2.2-fold $(P<0.05)$ increase in inner meniscus cells (Figure $4 b)$. The expression of the other two isoenzymes of $\mathrm{P} 4 \mathrm{H \alpha}$ 


\section{Outer meniscus cells}

(a)

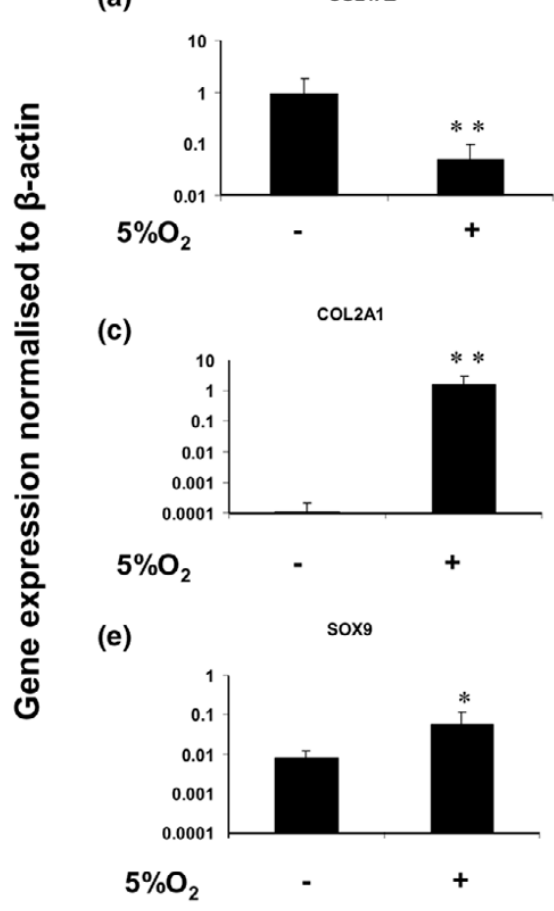

\section{Inner meniscus cells}

(b)

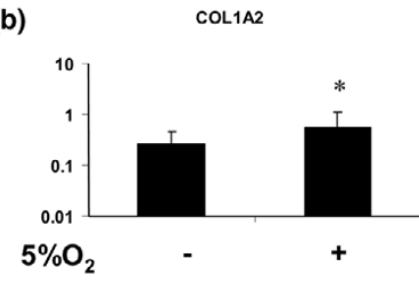

(d)

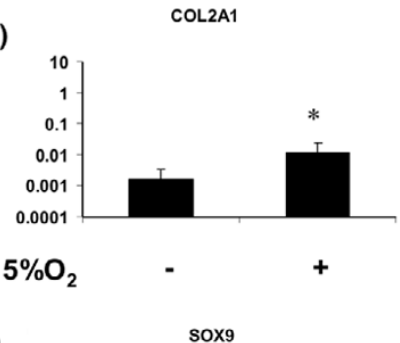

(f)

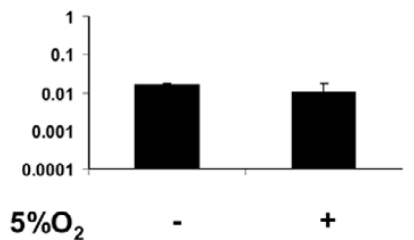

Collagen types I and II, and SOX9 gene expression in human meniscus cells. (a, b) Collagen type I alpha 2 (COL1A2) gene expression levels of cell aggregate cultures of (panel a) outer and (panel b) inner meniscus cells $(n=6)$ in $5 \%$ oxygen versus $20 \%$ oxygen. (c, d) Collagen type II alpha 1 (COL2A1) gene expression in aggregate cultures of (panel c) outer and (panel d) inner meniscus cells $(n=6)$ in $5 \%$ oxygen versus $20 \%$ oxygen. (e, f) SOX9 (Sry-related HMG box-9) gene expression levels of aggregate cultures of (panel e) outer and (panel f) inner meniscus cells $(n=6)$ in $5 \%$ oxygen versus $20 \%$ oxygen. ${ }^{\star} P<0.05,{ }^{* \star} P<0.01$ (by Student's unpaired $t$-test).

were unaffected in 5\% oxygen (data not shown), and the expression of $\mathrm{P} 4 \mathrm{H} \alpha(\mathrm{I})$ (and that of $\mathrm{P} 4 \mathrm{H} \alpha(\mathrm{II})$ and $\mathrm{P} 4 \mathrm{H} \alpha(\mathrm{III})$ ), under similar conditions, was unaltered in articular chondrocytes (Figure 5).

\section{HIF-1 $\alpha$ inhibitor, YC-1, blocks hypoxia induced expression of $\mathbf{P 4 H} \alpha(\mathrm{I})$ in human meniscus cells}

It has previously been established that the expression of $\mathrm{P} 4 \mathrm{H} \alpha(\mathrm{I})$ is susceptible to transcriptional control by HIF- $1 \alpha$ in low oxygen tension [52]. We therefore investigated the link between HIF-1 $\alpha$ and $\mathrm{P} 4 \mathrm{H} \alpha(\mathrm{I})$ by using the HIF-1 $\alpha$ inhibitor YC-1 [53,54]. In monolayer cultures of a mixed population of human meniscus cells in the presence and absence of $5 \%$ oxygen tension, $\mathrm{YC}-1$ inhibited the induction of $\mathrm{P} 4 \mathrm{H \alpha}(\mathrm{I})$ in a dose-dependent manner down to the level of $\mathrm{P} 4 \mathrm{H} \alpha(\mathrm{I})$ expression at 20\% oxygen tension (Figure 6 ). This represents evidence that the meniscus cells upregulated HIF-1 $\alpha$ transcriptional activity in response to $5 \%$ oxygen tension, and that this induced an increase in $\mathrm{P} 4 \mathrm{H} \alpha(\mathrm{I})$ expression.

\section{Discussion}

The lack of vasculature in the inner meniscus suggests that the resident cells exist in a hypoxic environment relative to meniscus cells in the outer meniscus. The results of the gene expression analysis provide new data on region-specific differences in mRNA expression in a panel of genes that are susceptible to transcriptional regulation by HIF- $1 \alpha$ in human meniscus. Furthermore, it supports the use of gene expression to distinguish tissues and cells from different regions of the meniscus. In addition, the study provides, for the first time, data on the response of cells isolated from the inner and outer meniscus regions to low oxygen tension in culture. It was interesting that cells isolated from the outer meniscus were relatively more responsive to $5 \%$ oxygen tension than were inner meniscus cells, based on the large modulation in gene expression of collagen types I and II, SOX9 and $\mathrm{P} 4 \mathrm{H} \alpha(\mathrm{I})$. Furthermore, it was particularly interesting that in contrast to the response of outer meniscus cell aggregates, increased SOX9 expression did not accompany the upregulated expression of type II collagen 
Figure 3

(a)

COL1A2

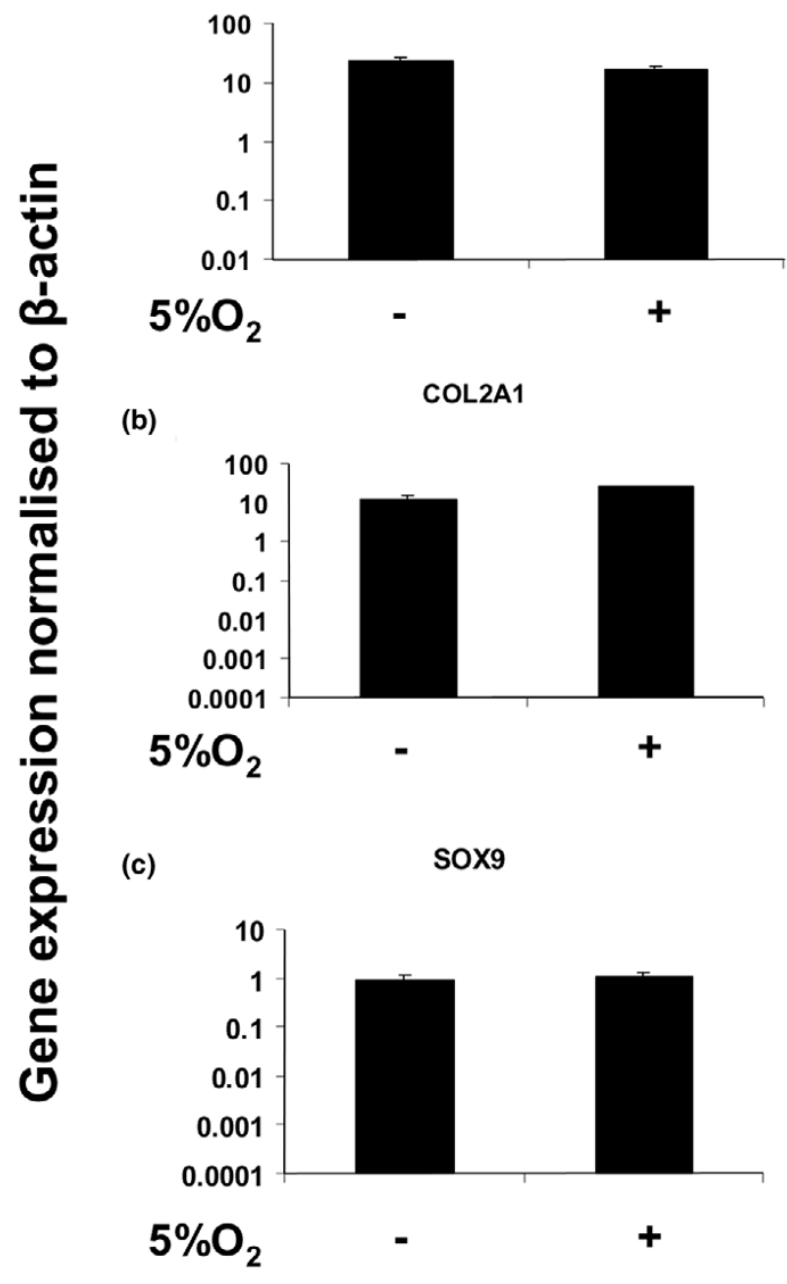

Collagen types I and II, and SOX9 gene expression in human articular chondrocytes. (a) Collagen type I alpha 2 (COL1A2) gene expression levels of aggregate cultures of articular chondrocytes $(n=3)$ in $5 \%$ oxygen versus $20 \%$ oxygen. (b) Collagen type II alpha 1 (COL2A1) gene expression in aggregate cultures of articular chondrocytes $(n=3)$ in 5\% oxygen versus 20\% oxygen. (c) SOX9 (Sry-related HMG box-9) gene expression levels of cell aggregate cultures of articular chondrocytes $(n=3)$ in $5 \%$ oxygen versus $20 \%$ oxygen. Student's unpaired $t$ test. Data are expressed as mean \pm standard deviation $(n=3)$.

in aggregate culture of inner meniscus cells in 5\% oxygen tension.

The level of type II collagen expression in aggregate culture of inner meniscus cells at $20 \%$ oxygen tension is consistent with previous reports $[19,23,24]$, which found that the inner meniscus exhibits a more chondrocytic phenotype than does the outer meniscus. The differential induction of SOX9 seen here in response to low oxygen tension suggested that SOX9 is a necessary transcription factor of type II collagen synthesis, but that it acts in conjunction with other factors, such as SOX5
Figure 4

\section{Outer meniscus cells}

(a)

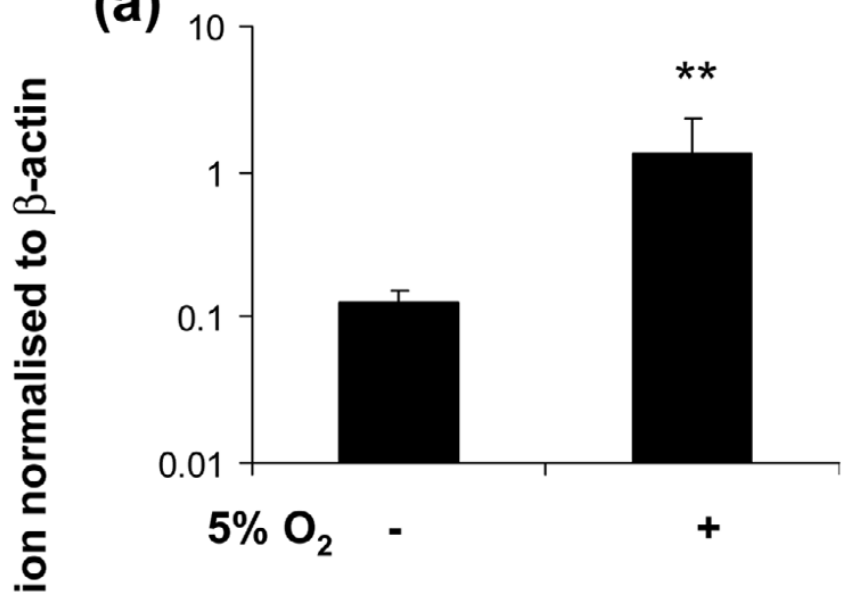

(b) Inner meniscus cells

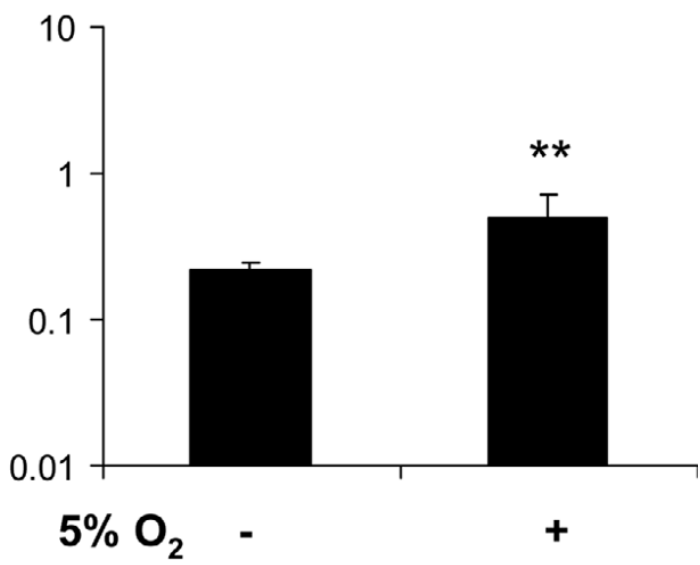

Collagen $\mathrm{P} 4 \mathrm{H} \alpha(\mathrm{I})$ gene expression in meniscus cell aggregates. Prolyl 4-hydroxylase (P4H) $\alpha(\mathrm{l})$ gene expression in (a) outer meniscus cell aggregates $(n=4)$ and $(\mathrm{b})$ inner meniscus cell aggregates $(n=4)$ in $5 \%$ oxygen versus $20 \%$ oxygen. Data are expressed as mean \pm standard deviation $(n=3)$. ${ }^{\star \star} P<0.01$ (by Student's unpaired $t$-test).

and SOX6, which are known enhancers of SOX9 [55,56]. It also suggests that increased SOX9 expression does not always correlate with type II collagen expression, and this is consistent with the findings of a previous report in articular chondrocytes [57]. Nevertheless, there were unquestionable differences between the responses of aggregate cultures of articular chondrocytes and meniscus cells (regardless of the region of cell isolation) to 5\% oxygen tension. The expression of the genes studied here was clearly not modulated in aggregate cultures of articular chondrocytes by $5 \%$ oxygen tension. This may therefore reflect a greater sensitivity of meniscus cells to oxygen tension. Naturally, articular chondrocytes exist in a completely avascular microenvironment, and an oxygen 


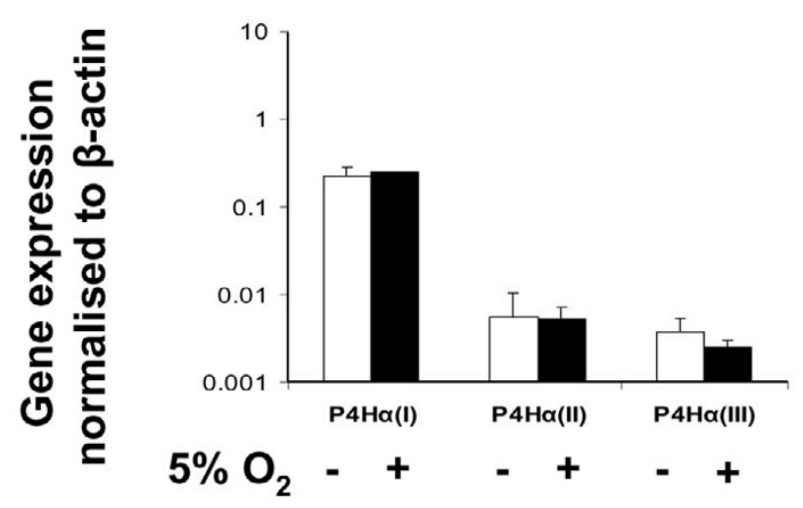

Collagen $\mathrm{P} 4 \mathrm{H}$ isoenzyme gene expression in articular chondrocytes aggregates. Prolyl 4-hydroxylase $(\mathrm{P} 4 \mathrm{H}) \alpha$ isoenzyme gene expression in cell aggregates of articular chondrocytes in $20 \%$ oxygen (white bars) and $5 \%$ oxygen (black bars). Data are expressed as mean \pm standard deviation $(n=3)$.

tension lower than 5\% may be required to elicit an hypoxic response in these cells.

This study shows that $\mathrm{P} 4 \mathrm{H} \alpha(\mathrm{I})$ was induced by $5 \%$ oxygen tension in aggregate culture of meniscus cells, regardless of the region of origin. In contrast, aggregate cultures of articular chondrocytes exhibited no comparable induction of $\mathrm{P} 4 \mathrm{H} \alpha$. Furthermore, the upregulation of $\mathrm{P} 4 \mathrm{H} \alpha(\mathrm{I})$ suggested that the response of meniscus cells to low oxygen tension is mediated by HIF-1 $\alpha$ [52], and this was confirmed by its inhibition by the HIF-1 $\alpha$ inhibitor YC-1 [53,54]. Previous studies have demonstrated YC-1 to block the expression of HIF- $1 \alpha$ and HIF-1 $\alpha$ regulated genes in the presence of soluble guanylyl cyclase inhibitors [54]. This strongly suggests that soluble guanylyl cyclase/cGMP signal transduction does not mediate the HIF$1 \alpha$ induction of $\mathrm{P} 4 \mathrm{H} \alpha(\mathrm{I})$.

To determine whether the in vitro response of meniscus cells to hypoxia was relevant to their behaviour in vivo, we analyzed intact meniscus tissue and found higher expression of HIF- $1 \alpha$, $\mathrm{P} 4 \mathrm{H} \alpha(\mathrm{I})$ and $\mathrm{PHD} 2$ in the inner region of the meniscus tissue as compared with the outer region. The pattern of expression correlated with the reported lower vascularity of the inner meniscus and a potentially more hypoxic microenvironment. The differential level of the constitutive expression of HIF-1 $\alpha$ and its target genes between the meniscus regions may thus reflect a mechanism that regulates the matrix-forming phenotype of the inner meniscus. The differential expression of HIF$1 \alpha$ seen here is of particular interest, because the action of HIF- $1 \alpha$ is modulated at the post-translational level. Furthermore, HIF- $1 \alpha$ has been shown to bind to CREB (cAMPresponse element-binding protein)-binding protein/p300, which SOX9 utilizes to exert its cartilage-specific type II collagen gene promoter activity $[58,59]$. These results suggest that
Figure 6

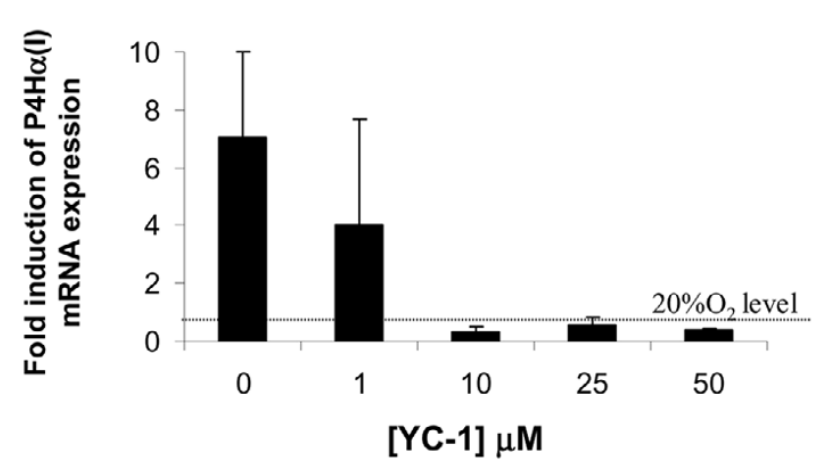

YC-1 mediated inhibition of hypoxic induction of $\mathrm{P} 4 \mathrm{H}$ in meniscus cell aggregates. Ratio of hypoxia (5\% oxygen) induced prolyl 4-hydroxylase $(\mathrm{P} 4 \mathrm{H}) \alpha(\mathrm{I})$ gene expression (post-normalization to $\beta$-actin) to $\mathrm{P} 4 \mathrm{H} \alpha(\mathrm{I})$ gene expression (post-normalization to $\beta$-actin) in $20 \%$ oxygen in monolayer culture of meniscus cells in the presence and absence of the hypoxia inducible factor- $1 \alpha$ inhibitor YC-1. Data are expressed as mean \pm standard deviation $(n=3)$.

the combination of the upregulation of SOX9, which activates type II collagen transcription in chondrogenic cells, and low oxygen induced upregulation of $\mathrm{P} 4 \mathrm{H} \alpha(\mathrm{I})$ may enhance the expression of type II collagen in human meniscus cells.

\section{Conclusion}

We demonstrate for the first time that cells isolated from the outer and inner regions of the meniscus respond differentially to lowered oxygen tension ( $5 \%$ oxygen). Based on the large modulation in gene expression of the panel of genes (collagen types I and II, SOX9 and $\mathrm{P} 4 \mathrm{H} \alpha(1))$ investigated in this study, it appears that cells from the outer meniscus are relatively more responsive to lowered oxygen tension than are their inner counterparts. Furthermore, the results show gene expression analysis to be a powerful tool in distinguishing tissue or cells from the outer and inner meniscus, and further extend the repertoire of genes that are constitutively and differentially expressed within specific regions of the meniscus. Most importantly, our findings revealed that HIF1 $\alpha$ and downstream target genes PHD2 and $\mathrm{P} 4 \mathrm{H} \alpha$ were upregulated in the inner meniscus relative to the outer meniscus, and that the response of meniscus cells (regardless of the region of cell isolation) to $5 \%$ oxygen tension was mediated by HIF- $1 \alpha$. Collectively, our data suggest that hypoxia driven expression of HIF- $1 \alpha$ may be important in determining the phenotype of the inner meniscus.

\section{Competing interests}

The authors declare that they have no competing interests.

\section{Authors' contributions}

ABA conceived, designed and executed the experiments described in this study, and was responsible for writing the initial versions of the manuscript. LMG and SJMS performed RNA isolation and cell culture experiments included in this manuscript. WSK was responsible for tissue procurement and 
processing. DMS and TEH supervised and oversaw the completion of the studies as well as the writing of the manuscript.

\section{Acknowledgements}

We should like to thank Drs Kaye Williams and Rachel Cowen (School of Pharmacy and Pharmaceutical Sciences, University of Manchester, UK) for technical advice on the YC-1 studies, and Drs Ann Canfield and Simon Tew (UKCTE, University of Manchester) for access to the hypoxia incubator and for discussion. This work was supported by grants from the European Framework V Program (Meniscus Regeneration Project Contract GRD-CT-2002-00703).

\section{References}

1. Ahmed AM: The load-bearing role of the knee meniscus. In Knee Meniscus: Basic and Clinical Foundations Edited by: Mow VC, Arnoczky SP, Jackson DW. New York: Raven Press, Ltd; 1992:59-73.

2. Levy IM, Torzilli PA, Fisch ID: The contribution of the menisci to the stabilty of the knee. In Knee Meniscus: Basic and Clinical Foundations Edited by: Mow VC, Arnoczky SP, Jackson DW. New York: Raven Press, Ltd; 1992:107-115.

3. Fairbank T: Knee joint changes after menisectomy. J Bone Joint Surg 1948, 30B:664-670.

4. Aagaard $\mathrm{H}$, Verdonk R: Function of the normal meniscus and consequences of meniscal resection. Scand J Med Sci Sports 1999, 9:134-140.

5. Wyland DJ, Guilak F, Elliott DM, Setton LA, Vail TP: Chondropathy after meniscal tear or partial meniscectomy in a canine model. J Orthop Res 2002, 20:996-1002.

6. Roos H, Adalberth T, Dahlberg L, Lohmander LS: Osteoarthritis of the knee after injury to the anterior cruciate ligament or meniscus: the influence of time and age. Osteoarthritis Cartilage 1995, 3:261-267.

7. Cox JS, Cordell LD: The degenerative effects of medial meniscus tears in dogs' knees. Clin Orthop Relat Res 1977, 125:236-242.

8. Cox JS, Nye CE, Schaefer WW, Woodstein IJ: The degenerative effects of partial and total resection of the medial meniscus in dogs' knees. Clin Orthop Relat Res 1975, 109:178-183.

9. Proctor CS, Schmidt MB, Whipple RR, Kelly MA, Mow VC: Material properties of the normal medial bovine meniscus. $J$ Orthop Res 1989, 7:771-782.

10. Ghadially FN, Thomas I, Yong N, Lalonde JM: Ultrastructure of rabbit semilunar cartilages. J Anat 1978, 125:499-517.

11. McDevitt CA, Miller RR, Spindler KP: The cells and cell matrix interactions of the meniscus. In Knee Meniscus: Basic and Clinical Foundations Edited by: Mow VC, Arnoczky SP, Jackson DW. New York: Raven Press; 1992:29-36.

12. Hellio Le Graverand MP, Ou Y, Schield-Yee T, Barclay L, Hart D, Natsume T, Rattner JB: The cells of the rabbit meniscus: their arrangement, interrelationship, morphological variations and cytoarchitecture. J Anat 2001, 198:525-535.

13. Nakata $K$, Shino $K$, Hamada M, Mae T, Miyama $T$, Shinjo $H$, Horibe $\mathrm{S}$, Tada $\mathrm{K}$, Ochi T, Yoshikawa H: Human meniscus cell: characterization of the primary culture and use for tissue engineering. Clin Orthop 2001, 391:S208-S218.

14. Arnoczky SP: Gross and vascular anatomy of the meniscus and its role in meniscal healing, regeneration, and remodelling. In Knee Meniscus: Basic and Clinical Foundations Edited by: Mow VC, Arnoczky SP, Jackson DW. New York: Raven Press Ltd; 1992:1-14

15. Arnoczky SP, Warren RF: Microvasculature of the human meniscus. Am J Sports Med 1982, 10:90-95.

16. Adams ME, Hukins DWL: The extracellular matrix of the meniscus. In Knee Meniscus: Basic and Clinical Foundations Edited by: Mow VC, Arnoczky SP, Jackson DW. New York: Raven Press Ltd; 1992:15-28.

17. McDevitt CA, Webber RJ: The ultrastructure and biochemistry of meniscal cartilage. Clin Orthop Relat Res 1990, 252:8-18.

18. Cheung HS: Distribution of type I, II, III and V in the pepsin solubilized collagens in bovine menisci. Connect Tissue Res 1987, 16:343-356.
19. Kambic HE, McDevitt CA: Spatial organization of types I and II collagen in the canine meniscus. J Orthop Res 2005, 23:142-149.

20. Roughley PJ, White RJ: The dermatan sulfate proteoglycans of the adult human meniscus. J Orthop Res 1992, 10:631-637.

21. Verdonk PC, Forsyth RG, Wang J, Almqvist KF, Verdonk R, Veys EM, Verbruggen G: Characterisation of human knee meniscus cell phenotype. Osteoarthritis Cartilage 2005, 13:548-560.

22. Ghadially FN, Lalonde JM, Wedge $\mathrm{JH}$ : Ultrastructure of normal and torn menisci of the human knee joint. J Anat 1983, 136:773-791.

23. Valiyaveettil M, Mort JS, McDevitt CA: The concentration, gene expression, and spatial distribution of aggrecan in canine articular cartilage, meniscus, and anterior and posterior cruciate ligaments: a new molecular distinction between hyaline cartilage and fibrocartilage in the knee joint. Connect Tissue Res 2005, 46:83-91.

24. Upton ML, Chen J, Setton LA: Region-specific constitutive gene expression in the adult porcine meniscus. J Orthop Res 2006, 24:1562-1570.

25. Melrose J, Smith S, Cake M, Read R, Whitelock J: Comparative spatial and temporal localisation of perlecan, aggrecan and type I, II and IV collagen in the ovine meniscus: an ageing study. Histochem Cell Biol 2005, 124:225-235.

26. Wilson AS, Legg PG, McNeur JC: Studies on the innervation of the medial meniscus in the human knee joint. Anat Rec 1969 165:485-491.

27. Arnoczky SP, Warren RF: The microvasculature of the meniscus and its response to injury. An experimental study in the dog. Am J Sports Med 1983, 11:131-141.

28. Arnoczky SP: Building a meniscus. Biologic considerations. Clin Orthop 1999, 367:S244-S253.

29. Adams SB Jr, Randolph MA, Gill TJ: Tissue engineering for meniscus repair. J Knee Surg 2005, 18:25-30.

30. Buma P, Ramrattan NN, van Tienen TG, Veth RPH: Tissue engineering of the meniscus. Biomaterials 2004, 25:1523-1532.

31. Marsano A, Millward-Sadler SJ, Salter DM, Adesida A, Hardingham T, Tognana E, Kon E, Chiari-Grisar C, Nehrer S, Jakob M, et al:: Differential cartilaginous tissue formation by human synovial membrane, fat pad, meniscus cells and articular chondrocytes. Osteoarthritis and Cartilage 2007, 15:48-58.

32. Sweigart MA, Athanasiou KA: Toward tissue engineering of the knee meniscus. Tissue Eng 2001, 7:111-129.

33. Domm C, Schunke M, Christesen K, Kurz B: Redifferentiation of dedifferentiated bovine articular chondrocytes in alginate culture under low oxygen tension. Osteoarthritis Cartilage 2002, 10:13-22.

34. Murphy CL, Sambanis A: Effect of oxygen tension on chondrocyte extracellular matrix accumulation. Connect Tissue Res 2001, 42:87-96.

35. Murphy CL, Sambanis A: Effect of oxygen tension and alginate encapsulation on restoration of the differentiated phenotype of passaged chondrocytes. Tissue Eng 2001, 7:791-803.

36. Murphy CL, Polak JM: Control of human articular chondrocyte differentiation by reduced oxygen tension. J Cell Physiol 2004, 199:451-459.

37. Grimshaw MJ, Mason RM: Modulation of bovine articular chondrocyte gene expression in vitro by oxygen tension. Osteoarthritis Cartilage 2001, 9:357-364.

38. Etherington PJ, Winlove P, Taylor P, Paleolog E, Miotla JM: VEGF release is associated with reduced oxygen tensions in experimental inflammatory arthritis. Clin Exp Rheumatol 2002, 20:799-805.

39. Brighton CT, Heppenstall RB: Oxygen tension in zones of the epiphyseal plate, the metaphysis and diaphysis. An in vitro and in vivo study in rats and rabbits. J Bone Joint Surg Am 1971, 53:719-728

40. Lund-Olesen K: Oxygen tension in synovial fluids. Arthritis Rheum 1970, 13:769-776.

41. Freshney R: Culture of Animal Cells: a Manual of Basic Techniques 4th edition. New York: Alan R Liss, Inc; 1987.

42. Adesida A, Tweats L, Millward-Sadler J, Salter D, Hardingham T: Cultured human meniscus cells are chondrogenic in pellet culture: this is enhanced by hypoxia and involves upregulation of prolyl 4-hydroxylase type I. Trans Orthop Res Soc 2005:1721. 
43. Adesida AB, Grady LM, Khan WS, Hardingham TE: The matrixforming phenotype of cultured human meniscus cells is enhanced after culture with fibroblast growth factor 2 and is further stimulated by hypoxia. Arthritis Res Ther 2006, 8:R61.

44. Berra E, Benizri E, Ginouves A, Volmat V, Roux D, Pouyssegur J: HIF prolyl-hydroxylase 2 is the key oxygen sensor setting low steady-state levels of HIF-1alpha in normoxia. EMBO J 2003, 22:4082-4090.

45. Semenza G: HIF-1, $\mathrm{O}_{2}$, and the 3 PHDs. How animal cells signal hypoxia to the nucleus. Cell 2001, 107:1-3.

46. Semenza G: Hypoxia-inducible factor 1: oxygen homeostasis and disease pathophysiology. Trends Mol Med 2001, 7:345-350.

47. Semenza GL: HIF-1 and mechanisms of hypoxia sensing. Curr Opin Cell Biol 2001, 13:167-171.

48. Semenza G: Signal transduction to hypoxia-inducible factor 1. Biochem Pharmacol 2002, 64:993-998.

49. Barbero A, Ploegert S, Heberer M, Martin I: Plasticity of clonal populations of dedifferentiated adult human articular chondrocytes. Arthritis Rheum 2003, 48:1315-1325.

50. Al-Taher A, Bashein A, Nolan T, Hollingsworth M, Brady G: Global cDNA amplification combined with real-time RT-PCR: accurate quantification of multiple human potassium channel genes at the single cell level. Yeast 2000, 17:201-210.

51. Livak KJ, Schmittgen TD: Analysis of relative gene expression data using real-time quantitative PCR and the 2- $\Delta \Delta C T$ method. Methods 2001, 25:402-408.

52. Takahashi Y, Takahashi S, Shiga Y, Yoshimi T, Miura T: Hypoxic induction of prolyl 4-hydroxylase alpha (I) in cultured cells. J Biol Chem 2000, 275:14139-14146.

53. Chun Y-S, Yeo E-J, Choi E, Teng C-M, Bae J-M, Kim M-S, Park JW: Inhibitory effect of YC-1 on the hypoxic induction of erythropoietin and vascular endothelial growth factor in Hep3B cells. Biochem Pharmacol 2001, 61:947-954.

54. Chun Y-S, Yeo E-J, Park J-W: Versatile pharmacological actions of YC-1: anti-platelet to anticancer. Cancer Lett 2004, 207:1-7.

55. Lefebvre V, Li P, de Crombrugghe B: A new long form of Sox5 (L-Sox5), Sox6 and Sox9 are coexpressed in chondrogenesis and cooperatively activate the type II collagen gene. EMBO J 1998, 17:5718-5733.

56. Ikeda T, Kamekura S, Mabuchi A, Kou I, Seki S, Takato T, Nakamura K, Kawaguchi $\mathrm{H}$, lkegawa $\mathrm{S}$, Chung UI: The combination of SOX5, SOX6, and SOX9 (the SOX trio) provides signals sufficient for induction of permanent cartilage. Arthritis Rheum 2004, 50:3561-3573.

57. Aigner T, Gebhard PM, Schmid E, Bau B, Harley V, Poschl E: SOX9 expression does not correlate with type II collagen expression in adult articular chondrocytes. Matrix Biol 2003, 22:363-372.

58. Ebert BL, Bunn HF: Regulation of transcription by hypoxia requires a multiprotein complex that includes hypoxia-inducible factor 1, an adjacent transcription factor, and p300/CREB binding protein. Mol Cell Biol 1998, 18:4089-4096.

59. Tsuda M, Takahashi S, Takahashi $Y$, Asahara H: Transcriptional co-activators CREB-binding protein and p300 regulate chondrocyte-specific gene expression via association with Sox9. J Biol Chem 2003, 278:27224-27229. 